\title{
The use of technology for online classes during the global pandemic: Challenges encountered by the schoolteachers in Pakistan
}

\author{
Rehman Nadia* | Wenlan Zhang | Mussarat Iqbal \\ School of Education, Shaanxi Normal University, Xian, China. \\ *Corresponding Author Emails: nadiarehman05@outlook.com | nadiarehman05@ gmail.com
}

\begin{abstract}
The lockdown after COVID-19 outbreak not only harmed the economy but also shut down all educational activity, resulting in a significant gap in learning and understanding among students worldwide. This mixed method study was conducted to know the media used by the teachers to teach online classes and challenges faced by the teachers' during online teaching in pandemic, which has hampered continued/online education due to interviews from the ten government teachers. Data was transcribed, coding was done, and five themes were analysed. The study showed that teachers mostly use WhatsApp and zoom meeting for online classes. Skype, Voov meeting and smart school is also use as a media for online teaching and learning purpose. Qualitative data revealed that teachers faced numerous problems during online classes, the biggest obstacle was the lack of electric power and low internet speed, along with that the parents and students' non-serious behaviour also affects the online education system. along with that lack of proper online forum, adversely affect the students' concepts, knowledge, and communication with their teachers while using the internet as a learning tool. Teachers are overburdened due to the large number of online classes being offered, affecting the quality of education.
\end{abstract}

\section{Article History}

Received:

June 11, 2021

Revised:

August 24, 2021

Re-revised:

September 30, 2021

Accepted:

October 10, 2021

Published:

October 29, 2021

Keywords: COVID-19 challenges, lockdown, online teaching, online classes, education technology, media of education, WhatsApp students' groups, Zoom classes.

How to Cite: Rehman, N., Zhang, W., \& Iqbal, M. (2021). The use of technology for online classes during the global pandemic: Challenges encountered by the schoolteachers in Pakistan. Liberal Arts and Social Sciences International Journal (LASSIJ), 5(2), 193-208. https://doi.org/10.47264/idea.lassij/5.2.13

Publisher's Note: IDEA PUBLISHERS (IDEA Publications Group) stands neutral with regard to the jurisdictional claims in the published maps and the institutional affiliations.

Copyright: @ 2021 The Author(s), published by IDEA PUBLISHERS (IDEA Publications Group).

Licensing: This is an Open Access article published under the Creative Commons AttributionNonCommercial 4.0 International License (http://creativecommons.org/licenses/by-nc/4.0/) 


\section{Introduction}

Due to the widespread presence of COVID-19, educational institutions were closed, and students were instructed to remain at home. By March 11, 2020, the novel coronavirus infection originating in Wuhan, China, quickly turned into a pandemic. The COVID-19 outbreak is traumatizing for all of us in society. Prevention and control of the epidemic are in a time that is critical (Mohsin et al., 2020). The coronavirus has also adversely affected the educational system in addition to stifling economic activity. The $\$ 600$ billion coronaviruses disrupted the higher education sector (Shaheen et al., 2020; Bloomberg, 2020). Globally, students and educators were affected by the cause and effect of coronavirus, as universities and colleges were ordered to close all the academic departments after the virus was declared an emergency in several countries. Such school closings have occurred in 44 emerging and developed countries, impacting hundreds of millions globally. The problem has a much more significant impact on schools that do not have access to e-learning. According to UNESCO, the COVID19 epidemic has impacted at least 290.5 million students globally in terms of education (UNESCO, 2020). COVID-19 has affected every aspect of human life worldwide, including education, science, sports, entertainment, transportation, religion, social gatherings/interaction, economics, industry, and politics. The world was clearly in turmoil due to the COVID-19 attacks, but the reality of the situation was tough, and the education system was one of the hardest hits by the Outbreak (Jan et al., 2020; Onyema et al., 2020).

As a result of the 2019-2020 coronavirus outbreak, schools, institutions, and colleges worldwide have been forced to close or close their doors entirely. According to the United Nations, approximately 1.723 billion students were affected by school closures due to the epidemic by mid-April 2020. According to the United Nations Educational, Scientific, and Cultural Organization (UNESCO), 191 countries have enacted nationwide closures. In contrast, five have undertaken local closures, affecting approximately $98.4 \%$ of the world's student population (UNESCO, 2020). Various social and economic issues were brought to light due to the school closures caused by COVID-19, including student debt, digital literacy, food shortages, and homelessness. Other problems, including health care, housing, access to the Internet and disability awareness. It had a particularly negative impact on young children and their families, resulting in school delays, poor nutrition, day-care worries, and increased economic expenditures for families unable to find employment. In response to school closures, colleges recommended that students use distant learning programs and open programs, educational technologies that schools and teachers can utilize to access students remotely and avoid academic interruption (Ngumbi, 2020).

The coronavirus outbreak has impacted every nation and race on the planet. The world has been overrun by COVID-19's quick expansion and catastrophic consequences, which has caused the world to be invaded. A mix of non-pharmaceutical remedies and preventive measures, such as social distance and self-isolation, have brought the broad closure of primary, secondary and higher education facilities in more than 100 countries (Onyema et al., 2020). The coronavirus pandemic knows no bounds, and its impacts are extensive and swift in their implementation. In just a few months after the disease's onset, millions of individuals have been forced to stay at home, observe self-isolation, and work and learn from the comfort of their own homes. Individuals' freedom to travel, exchange, and form associations have been curtailed in recent years. It is estimated that thousands of individuals, primarily women and the elderly, died as a result of COVID-19, which not only brought numerous countries to a complete halt and murdered thousands. It is concerning to note that new COVID-19 cases and 
deaths are continuously increasing according to research conducted worldwide, including the United States of America, Africa, Asia, and Europe.

According to the World Health Organization (WHO), there are one million COVID-19 cases globally as of April 2020, with more than 220,000 deaths. That more than 2000 COVID-19 fatalities were documented in a single day, despite the country's strong commitment to combating the virus, was particularly troubling. There is an increase in the number of deaths caused by coronaviruses, and there is no apparent treatments insight. Nowhere on the earth does the disease appear to be slowing or even decreasing. In reaction to the emergence of COVID-19, President Donald Trump of the United States invoked the "Defence Production Act". As a result of the large number of new coronavirus infections occurring across the country, the government declared a national emergency. According to the United States government's vote, a \$2 trillion stimulus package with the European Union would be implemented to combat the Coronavirus pandemic and provide relief to individuals and companies affected by the Outbreak. Similar precautions were taken in several other nations, notably Germany, and the pandemic's economic impact was reduced by USD 810 billion. The virus, on the other hand, spread quite quickly around the world. All across the globe, the COVID-19 conference has had an impact on fields as diverse as education, research, sports, culture, transportation (including air travel), religion, social gatherings/interaction, economics, commerce, and politics. Following the COVID-19 attack, the world was in disarray, the reality was harsh, and the education sector was one of the most severely affected by the Coronavirus pandemic (Khan et al., 2021; Onyema et al., 2020).

The study's main objective was to explore the media used by the teachers for teaching and learning online classes. The study also explored the problems and possibilities Pakistani teachers faced during the online teaching and learning process during COVID-19's lockdown, which has hampered continued/online education.

Figure 1: Conceptual framework

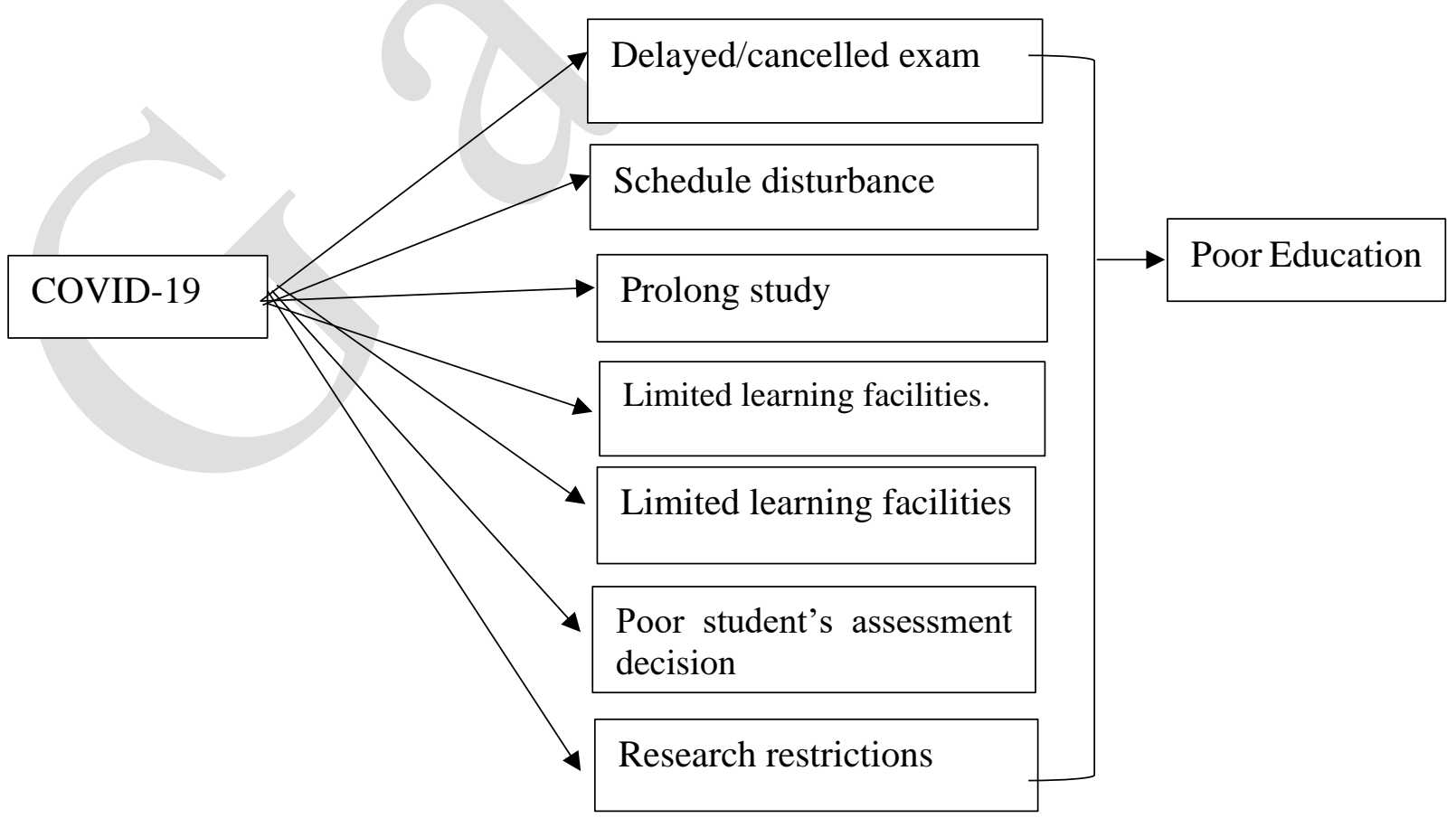




\section{Literature review}

\subsection{Overview of Coronavirus disease in Pakistan}

The WHO recognized the COVID-19 outbreak as the sixth emergency health service in the world on 30 January 2020 (SPHEC) (Bilgin et al., 2020). This is not the first time an outbreak of coronavirus has occurred. Previous coronavirus-related outbreaks include the Middle East Severe ARS-CoV epidemic, and the U.S. Coronavirus-related Respiratory Syndrome (CRS) epidemic (WHO, 2019). Countries on the border, such as China, which saw the first COVID19 epidemic, are particularly vulnerable. Italy has the most excellent COVID-19 mortality rate in the Western hemisphere, while Iran has the most excellent COVID-19 mortality rate in the Northern hemisphere after Italy. On February 26, 2020, the Pakistani government's health ministry declared the inaugural COVID-19 event in Karachi, Sindh province (Saqlain et al., 2020). Another case was reported in Islamabad the next day, according to the Federal Ministry of Health. The absolute number of confirmed (COVID-19 Positive) cases across Pakistan has surpassed the total number of documented (COVID-19 Positive) in just fifteen days. The most significant number was occurring in Sindh and the lowest in Gilgit Baltistan (Geo News, 2020). Any recorded case has recently travelled to Iran, Syria, or London, among other places. And these occurrences are now proliferating at an alarming rate, putting the situation in jeopardy (National Institute of Health Islamabad, 2020).

With the constant increase in the positive CVOID-19 cases, Pakistan's geographic location necessitates comprehensive action plans and management systems. A public presentation of the National Action Plan for the Corona Virus Disease Preparedness \& Response (CVDPR) by Pakistan's Ministry of National Health Services, Regulation \& Coordination took place on February 12, 2021 through a helicopter flight. With the National Coronavirus Action Plan, the goal is to contain the spread of the disease and strengthen the emergency preparedness across the country and community so that the potential events of COVID-19, such as local, regional and national outbreaks, do not affect the health of the Pakistani populations and society significantly (Waris et al., 2020). To counteract the COVID-19 epidemic, the Pakistani government has adopted several different actions thus far. It is discussed in this study the various measures taken by the Pakistani government against the COVID-19 Outbreak, including the establishment of designated hospitals and quarantine centres, the provision of testing and treatment facilities, public education, and local community response to the COVID19 Outbreak (Waris et al., 2020).

According to the latest available data, on Monday, 6 April 2020, the Pakistani Ministry of Health had confirmed a total of 3,277 cases with 18 critical cases and 50 deaths. Punjab was reported mostly in 1493, followed by Sindh (881), Khyber Pakhtunkhwa (405), Balochistan (191), Baltistan Gilgit (210), Federal (82), and Jammu Azad and Cashmire, respectively. Khyber Pakhtunkhwa (80), Punjab (15), Sindh (15), Gilgit Baltistan (3) and Balochistan were the provinces with the greatest casualties. As can be seen in table-1, 85 people from Sindh, 30 from KP, 17 from Balochistan and 25 from Punjab have recovered. As can be seen in Table 1, nine patients recovered from GB and nine from AJK. United States Health Services (The Ministry of National Health Services, 2020).

\subsection{Effect on education}

As the Covid-19 pandemic spread throughout the world, many countries' educational systems 
are suffering as a result of the decline of digital schooling. Universities in India, Pakistan, and Afghanistan are ill-prepared for online or remote learning. At the same time, their campuses are closed, and their students return home as part of a South Asia-wide coronavirus prevention program. The Higher Education Commission (HEC) Pakistan has requested that universities collaborate with faculty to build online courses broadcast to students as soon as possible in response to the country's coronavirus outbreak. Because of the coronavirus pandemic, we are all at risk, and online education is the only method to safeguard the safety of instructors and students. Pakistan's online system, on the other hand, has faults; the majority of pupils do not have cellular phones or internet access, which results in their failure. It was impossible to align pre-Covid-19 with the educational system, resulting in kids and their prospective chances after the pandemic being negatively affected. As a result of the pandemic, many students have returned from abroad, and most are stuck in their home country after their flights have been cancelled, posing research, finance, and time management issues. Recently, Pakistani universities have been forced to close due to terrorist attacks and political threats, but universities have yet to pursue online education. Because most students do not have smartphones or computers to take online classes, the system will face difficulties due to the abrupt transition to online learning (Aslam et al., 2020; Saeed et al., 2021).

Several government schools in Pakistan shared that the government does not provide students with books. Students do not even have mobile access from their parents due to unsatisfactory conditions. May be this lockdown gave us an idea about changing our educational facilities to get the most out of them. This can be seen as an opportunity to help redevelop learning environments and neighbourhoods. Above all, this harsh wake-up call should encourage all relevant stakeholders to consider schools' true purpose and future education. Students attempt to persuade experts to review class decisions and tests on all available websites but are largely ignored. Instead of providing scholars with a logical path forward in this crisis, HEC and HEI administrators introduce policies to confuse students. Conversely, COVID-19 makes Pakistan's online education system inoperable. Most students regard education and science highly. Government and educational institutions are primarily responsible for delivering high-quality education. HEC is tasked with quality education without compromising established expectations. This unfortunate situation needs smart contributions from those concerned. Developed countries, the WHO and Pakistan's Prime Minister have all urged people to learn to live with coronavirus for a while before a long-term cure is found. State, HEC, and universities must adopt a futuristic, practical, and ambitious approach to safeguarding millions of students across the country for the sole purpose of education.

As technology has progressed in the current century, technology has become a significant factor in the education system. However, with regard to education, learning or acquiring knowledge, abilities, values, convictions and habits, things have changed, as they have changed in the past; technology, with advances in the new era, is becoming an integral part of education, of learning or gaining knowledge, skills and values (Khanna \& Prasad, 2020). Technological dependency is therefore inevitable. The epidemic has sped the move to a digitalized system (Anderson, 2004). Changes that have previously occurred in universities and colleges have now been pushed into online classes, and other platforms used to monitor pupils' progress. It should be noted that schools and schools have developed a way to communicate with children at home (Richardson et al., 2020). The present study identifies the challenges that emerged during the Covid-19 pandemic during online schooling and possible solutions. Teachers and students of different ages face these problems. Certain concerns are technological, nontechnical, and related to resources, funds, and economic challenges (Waris et al., 2020). Our 
study focuses on these characteristics and interviews with ten teachers as primary data, which we utilize to analyse the situation.

Interaction between students at school and college became increasingly difficult during online classes and it became tough to develop solutions to basic concerns during online education. Since the vast majority of the population of Pakistan lives in rural areas, there is a serious dearth of internet connection in most of the country's towns. Proper hardware and software, one of the biggest challenges encountered during the epidemic was a shortage of equipment in practically every household when schools and institutions began teaching online (Adnan \& Anwar, 2020). Problem solving (in terms of technology) capabilities: As we learn to use technology in our everyday lives, we face certain issues for which we need to find a solution. We will not always be able to ask for help, therefore we have to learn how to solve problems ourselves. Piracy and privacy are prominent problems in the digital age as the vast majority of people have Internet access. There is much concern regarding the steps to combat piracy that need to be done (Khanna \& Prasad, 2020).

\section{Theoretical framework}

Technological Pedagogical Content Knowledge (TPACK) is a famous teacher knowledge model for the efficient use of digital technology in the classroom (Schmid et al., 2021). Technical Pedagogical Content Knowledge is the best-known model of teacher competency in digital technology (Koehler \& Mishra, 2009; Mishra \& Koehler, 2006; Voogt et al., 2013). Teachers must mix several types of knowledge to educate effectively using technology in this method, which extends Shulman's $(1986 ; 1987)$ pedagogical content knowledge framework. This list includes the three primary components of Pedagogical Knowledge (PK), Content Knowledge (CK), and Technological Knowledge (TK). In this study, we shall merely examine the technology and usefulness of instructors. The TPACK framework has been mainly used according to Chai et al. (2013) to evaluate teachers' levels of skills and build professional development activities of teachers to develop TPACK (Chai et al., 2013).

TPACK is a hypothesis that defines what teachers need to know to educate their pupils successfully and to use technology. It seeks to discover the types of knowledge instructors who need technology integrated into their courses, recognising that teacher knowledge is complex, diverse and situational. According to Valtonen et al. (2020), this paradigm expands Shulman's idea of educational content in Koehler and Mishra's study in 2006. The TPACK framework is organised around seven features and according to Koehler and Mishra (2006), describes the seven fields of teacher knowledge based on effective teaching. For the goal of this study however, we shall just look at the fields of technology.

\subsection{Technology Knowledge (TK)}

Technology expertise spans a wide spectrum of technology from low-tech equipment such as crayon and paper to high-tech devices such as desktop computers, Internet connections, laptops, screenings, printers, projectors, scanners, speakers, tablets.

\subsection{Technological Pedagogical Knowledge (TPK)}

The Technological Pedagogical Knowledge means a grasp of how different technologies can be utilized in classroom and how it can transform educational training for the instructors. 


\subsection{Technological Content Knowledge (TCK)}

Known as Technical Content Understanding as to how technology can develop new representations for specific materials. It indicates that teachers recognize that they may influence how pupils practice and understand issues in a certain curriculum field by applying a certain technology.

\subsection{Technological Pedagogical Content Knowledge (TPACK)}

Teachers must have technological pedagogical expertise to integrate technology into their education in every field. Teachers gain intuitive awareness of the complicated interaction between three basic knowledge components (CK, PK, TK) by teaching content utilizing appropriate pedagogical approaches and technologies (Santos \& Castro, 2021). Although the country lacks Internet access and teacher comprehension of technology in Pakistan's public schools, instructors are equipped to employ technology in their educational and learning processes (Rehman et al., 2021).

The condition of technology is always evolving (Koehler \& Mishra 2009). It is extremely dynamic, and simple changes occur. Teachers must therefore be highly active and ready for up-to-date technological expertise. Developing this degree of technological expertise allows a person to do a wide range of jobs with IT and develop novel techniques to completing a given activity (Koehler \& Mishra, 2009). Teachers require more than just the topic they teach. A teacher must be skilled in several technologies and academic fields. Teachers should know which technology is most suitable for the subject and display the material using this technology correctly. There are several technologies, each with its quality (Zaidi \& Hussain, 2019).

\section{Research methodology}

For the present study, a mixed-method approach was used. In the mixed method approach, the explanatory sequential design was adopted. There are two interactive aspects to the sequential explanation (also known as the explanatory design). Quantitative data collection and analysis is the initial phase in this design and the essential step in addressing the questions of the study This first stage is followed by the collection and analysis of qualitative data. The second qualitative stage of the study will follow the results of the first quantitative phase. The researcher deduces the contribution of qualitative findings to quantitative results (Creswell, 2021). To investigate the media used by instructors to conduct online classes, 100 teachers were chosen, a questionnaire was developed, and it was distributed to ten schools in Rawalpindi and Islamabad, Pakistan. To investigate the issues faced by teachers during online classes, ten teachers were chosen at random from among a hundred to be interviewed.

\subsection{Research instrument}

A questionnaire was prepared to examine the media used by the teachers to teach online classes. The interview protocol was prepared to inspect the challenges faced by the teachers during COVID-19.

\subsection{Respondents}

The respondents of the study were randomly selected. The questionnaire was distributed online 
as an instrument using the WhatsApp platform. This questionnaire was distributed to the teachers in the high schools. A total of 100 teachers volunteered to participate in this study. The respondent demographic is shown in table 1 . From 100 teachers only ten teachers presented themselves for the interview.

Table-1: Demographic profile of the teachers

\begin{tabular}{|l|c|}
\hline Demographics variable & Frequency \\
\hline Gender & Female 100 \\
Female & \\
\hline Education, B.Ed. & 20 \\
MA & 50 \\
M.Phil. & 30 \\
\hline Teaching experience & 10 \\
$<5$ years & 40 \\
5-10 years & 09 \\
10-15 years & 20 \\
15-20 years & 21 \\
\hline <20 years & \\
\hline
\end{tabular}

\section{Results and discussion}

\subsection{Technology used in online learning}

Internet and technology are incredibly vital for online learning as a support system. As a mechanism for distance preservation in this epidemic is in place, online learning is used for distant learning in this epidemic of COVID-19. Some information and technology products can be used in the online classroom. Teachers can use media, applications and platforms to create curricula and teach students skills (Fuad et al., 2020). The findings of the survey reveal the media used by schoolteachers for more than 6 months of online learning. As indicated in Table 2 the teachers at Rawalpindi and Islamabad use 10 various kinds of learning material, applications and platforms. This range of media aims to prevent students from growing bored during online learning because at every meeting they are exposed to something new. One of the goals of this medium is to facilitate communication between the teacher and his or her students through the provision of material or skill messages. The information must be well received in order to understand and generate behavioural changes (Anshari et al., 2017). Effectiveness of communication in learning is also a factor in the success of learning activities (O'Flaherty \& Phillips 2015).

Table-2:Technology-based media used in online learning

\begin{tabular}{|c|l|c|c|c|c|}
\hline No & Types of media & Frequency & No & Types of media & Frequency \\
\hline 1 & Skype & 10 & 8 & Smart School & 5 \\
\hline 2 & Google Classroom & 2 & 9 & Facebook & 5 \\
\hline 3 & Zoom Meeting & 23 & 10 & Voov meeting & 08 \\
\hline 4 & WhatsApp & 40 & & & \\
\hline 5 & Google classroom & 5 & & & \\
\hline 6 & Google Form & 1 & & & \\
\hline 7 & Email & 1 & & & \\
\hline
\end{tabular}




\subsection{Technology used in online learning}

Teachers most often choose and use WhatsApp and Zoom meetings among the various online learning mediums accessible. Almost half (40\%) of the participants during the COVID-19 outbreak used WhatsApp as the primary medium for education. WhatsApp is readily available on all smartphones and is largely used for daily communication by teachers and parents. Teachers can publish homework or tasks on a WhstApp effortlessly. WhatsApp is the most popular free chat programme. Students may easily provide their professors with images and videos of their schoolwork. WhatsApp is easy to use compared to other applications, no login problems exist, and parents can easily watch the activity of their children. Teachers utilise WhatsApp due of its advantages such as ease of use, high access, high contact between students and teachers and learning from anywhere and anytime (Gon \& Rawekar, 2017).

WhatsApp helps to increase success and develop favourable attitudes towards WhatsApp use in classes among students (Cetinkaya, 2017). It can also be used to motivate students to study (Amry, 2014). The second most popular media is Zoom Meeting (23 percent). The teacher is better off teaching a large number of students online. In addition, the teacher can publish numerous questions simultaneously, and pupils can share their screens with other students. Following that, teachers employ Skype $(10 \%)$ and Voov (8\%) to conduct online classes. Teachers can provide material on the subject taught using a skype and Voov conference. Teachers can submit instructional materials, give student activities and post student grades so that they can see outcomes immediately.

Several platforms still offer the ability to learn online, like Google Classroom, Facebook and Smart School, although their use among Pakistani teachers is still restricted. One reason is that elderly teachers with more than 20 years of teaching experience are less able to learn and choose "simpler and more common" solutions such as WhatsApp. You have limited experience with ICT; thus, you hesitate to use it in your lectures (Chu \& Chu, 2010). Given the significant role that technology can play in online learning during this epidemic, it is more effective to equip instructors with ICT skills and to try and integrate them in their classrooms. Teachers must find unique ways of attracting students' interest in classroom learning and help them comprehend how they learn with ICT and materials.

\section{Qualitative data analysis}

\subsection{Societal challenge}

Our actions and limitations cause the majority of problems. First and foremost, students' cynicism about online education, as well as the general public's dread of using technological devices for educational and learning reasons, is unfounded. It is also a severe problem for conventional family systems to provide personal home space for members who need to work or study from home. This is especially true for families when both parents and children must work or study from home. Additionally, our non-disciplined, distracted e-learning lifestyle encourages more students to enrol in distance-learning courses. Even if online learning requires less attention, e-learning shyness and camera aversion are still students and teachers must deal with. Another significant concern is a lack of tolerance for technological difficulties and wrath displayed in response to repeated delays, interruptions, and other disturbances. The situation has gotten worse as a result of a lack of understanding of digital learning ethics. 


\subsection{Lack of students' behaviour}

After the COVID-19 outbreak, the Ministry of Federal Education and Professional Training, Pakistan announced that all educational institutions would remain closed, completely neglecting the requirements of the students. Students were opposed to the movements because of concerns about productivity and accessibility, but the institution's capacity was created the same way that every other revolution has been built. Recently, Pakistan's Premier Imran Khan announced a tele-education channel to keep students connected to their education through specialized lectures from grades I to XII. The track will be available to students throughout Pakistan. This project has necessitated significant effort on the part of all parties involved. They should always be acknowledged since their efforts have far-reaching ramifications for the education of our future kids.

\subsection{Technical problems}

The technical problem list is not as long as it has been with its predecessor. The most important issue, however, is the lack of accessibility to the Internet in rural areas, which inhibits students from using online education in those places. With a few exceptions, bandwidth limitations in the country are exacerbating the unhappiness of most students, coupled with the growing use of unstable Internet infrastructure. The expense of high-speed internet is another stumbling block. Millions of Pakistani students cannot access the basics of connected life such as cell phones and the Internet due to a lack of Internet access. "There is often no electricity, quite often the internet goes down, and there is wireless $3 \mathrm{G} / 4 \mathrm{G}$ coverage in places where there is no internet. Some remote students ride out of town on a motorcycle in the morning, braving temperatures of up to $50^{\circ} \mathrm{C}$., to download lectures at a friend's home. In a phone interview, one of the teachers says, "It is just a lot of work to get there" (Teacher E). While there were previously huge technical gaps in Pakistan (22.8 million of over 70 million young people in the country are out), the coronavirus outbreak brought to the fore the country's significant technological imbalances. According to one of the teachers, a lot of Pakistanis are about to drop out of schools or universities due to the pandemic.

Hundreds of students throughout Pakistan demonstrated against the decision of the government to hold online lessons last month. At the same time, poor Internet connectivity remains a major problem, particularly in rural regions such as Baluchistan, Khyber Pakhtunkhwa and GilgitBaltistan, according to the BBC. According to the Pakistan Telecommunications Authority, residential broadband is prohibitively expensive outside of Pakistan's main cities. Smartphone penetration is at $51 \%$ this year, and just one million school-aged children have everyday access to digital devices and bandwidth. On the other hand, Pakistani children have access to televisions in their homes, which is why the government claims to have started its distance learning plan for coronavirus with a dedicated television channel called Tele school. In barely two weeks after schools were closed, the track, which began showing material from four Pakistani enterprises include ed-tech grades 1-12 on state-owned PTV Home, which has a subscriber base of more than 54 million people, was launched on April,13. The addition of a text messaging system with 250,000 users, which was launched in late May, allows parents and students to contact specialized teachers.

One of the schoolteachers mentioned about the interview of Minister of Federal Education, Shafqat Mahmood, who promised to establish a radio school system for online learning to reach the students of most remote areas. A digital content on-demand e-learning system and a local 
network system that will help the students providing content to the most depleted areas. Science teacher also mentioned that the prime minister would also approve a "student relief package" that would include low-cost web subscriptions and cheaper cell phones. (Teacher B). Even smartphone-enabled households have issues. Teachers also claimed the economic issues of every third home with only one smartphone and six children to educate at home. All of the children are in separate classrooms, with different content to be learned. She further explained that. Students sometimes borrow phones from grandparents, friends and other family members for online classes. these are the problems that students share with their teachers that highly affect their studies

\subsection{Students regulatory}

The government and its regulatory hand represent another set of barriers. As the government is mostly responsible for quality, the government is responsible for the absence of a default online learning plan. To make matters worse, it seems that the national government and regulatory bodies are not on the same page. For example, a government ministry issued a notice to close schools and universities, while a regulatory authority authorized online classes. This problem causes immense difficulties for learners in general. Holistic, political, and hierarchical processes focused on traditional concepts of public administration hamper e-learning. The absence of accountability and reliable data for effective and timely policies are two more problems that need to be resolved in the future. In Pakistan, where more than 300,000 schools have been shuttered in March because of an outbreak of coronavirus, the national Government has used the lock-out period to take online teachers for students who are asked to take online courses by the Ministry of Education to avoid student losses. Because of a pandemic, most teachers were forced to teach online due to their first-hand online teaching experience. Most teachers, therefore, chose asynchronous approaches based on their skills, ICT experience, and available resources.

Teachers at government primary and secondary schools are not using ICT for educational purposes, causing difficulties during online teaching. "I am a biology teacher, and when I first used ICT while teaching biology, I had difficulty teaching material when I could not see the students" (Teacher A). Most of the qualified teachers could not provide information due to a lack of preparation and inaccurate information. As a result, students lose interest. Another teacher brought that up. "Before beginning online courses, the government should provide teachers with instruction. Teaching in the classroom and online are two very different things. Teachers should have enough materials, even though we do not always know whether or not the students are grasping the concepts" (Teacher B). "It's hard to teach online without training, sometimes the couple that is only of response during class. Other students don't show interest, don't complete assignments, and do not care about quizzes" (Teacher C). Another teacher has claimed, "We have never used an educational app before; therefore, most teachers set up a WhatsApp group; pupils who have not been charged to school are not involved, so we cover the course without them" (Teacher D)". Another instructor stressed the need of tackling current concerns, such as investing in teachers to enhance results.

\subsection{Class schedule}

Another problem facing teachers during online classes is class scheduling. Because most students do not follow the class schedule, the teacher must wait long for all students to arrive. "Non-serious students do not follow the class timing and present lame excuses. Due to which 
class schedule and test schedule get disturbed" (Teacher X). Pakistan faces an energy crisis, with most regions losing power for several hours, forcing students to arrive late. Another teacher indicated that the student is not interested in being late or at any time not paying attention to the teacher." Students become preoccupied with talking or texting during class, according to another teacher. The majority of students watch instructional videos on their older brother's tablet. "However, get busy and take the TikTok and messenger class seriously" (Teacher Y). "A lack of understanding about the ethics of e-learning has exacerbated the situation," teachers said" (Teacher X).

\subsection{Poor assessment}

Teachers' evaluation was another major issue that teachers had to deal with. It is difficult for teachers to rate students' work because there are more opportunities for cheating and plagiarism in online classes, especially if you are not well-versed in technology at a high school level. "We are having difficulty assessing students' work because we only posted questions on WhatsApp community or Zoom, one teacher said, "Most students open their books and copy from the internet, which the teachers could not manage." "Some students copy the material from the internet and give us pictures," another instructor explained. Teachers must consider their students' various needs, and they have different forms of content and solutions depending on whether a child has WhatsApp, SMS, or no phone connectivity.

\section{Conclusion}

Since the clouds still have a silver line, it is time to look for the bright qualities of these terrible situations. One prerequisite for a paradigm shift from traditional education to inclusive effective and equitable e-learning is the development of a standard and complete e-learning strategy with the permission of all stakeholders. Quantitative data revealed that mostly use application by the teachers is WhatsApp and zoom meeting for teaching online classes. From the survey study concluded that teachers must equip themselves with advance technology. Government should train teachers about new and advance technology application for teaching and learning process. Qualitative data revealed that teachers are facing serious issues during online teaching. These issues need to address and sort out at government level. All schools must give equal access to technological resources such as computers, high-speed Internet and online teaching platforms to guarantee the success of online learning. In addition, asynchronous learning modes based on shorter-term lectures with offline monitoring, discussion fora and a new cognitive study style are required for the necessary lesson hour. Finally, but certainly not least, improving the skills and experience of faculty members is crucial for them to conduct this online education effectively. Otherwise, if education is interrupted, only a semblance of compromise, delay, or even the careers of future generations are risked. We know that integrating digital education in low-resource areas is exceedingly complex, and significant challenges must be overcome.

The majority of Pakistani homes now have at least one smartphone. Still, for most students from low-income families, the availability of internet data is the most significant impediment to their success, particularly in rural areas. The government is therefore reaching out to the top telecommunications companies in Pakistan to see whether they are keen to collaborate on the national emergency response digital education program to subsidise the internet data from the instructional content on the government website. It would be useful if the government developed a strategy to provide the low-income households with educational plans of internet 
data. Moreover, the government realises that literacy, especially the digital literacy, might be an obstacle to many people's engagement. While high-cost schools can go towards online teaching and learning program, low-cost institutions cannot succeed. Therefore, many organizations are trying to introduce simple technology and collaborate with low-cost schools to understand their requirements better and create chances for their students to share materials and monitor progress quickly.

\section{Declaration of conflict of interest}

The author(s) declared no potential conflicts of interest(s) with respect to the research, authorship, and/or publication of this article.

\section{Funding}

The author(s) received no financial support for the research, authorship and/or publication of this article.

\section{References}

Adnan, M., \& Anwar, K. (2020). Online learning amid the COVID-19 pandemic: Students' perspectives. Online Submission, 2(1), 45-51. https://eric.ed.gov/?id=ED606496

Anderson, T. (2004). Teaching in an online learning context. Theory and practice of online learning, 273-294.

https://citeseerx.ist.psu.edu/viewdoc/download?doi=10.1.1.511.1503\&rep=rep1\&ty pe $=$ pdf

Amry, A. B. (2014). The impact of WhatsApp mobile social learning on the achievement and attitudes of female students compared with face to face learning in the classroom. $\begin{array}{llll}\text { European Scientific } & \text { Journal, } & 10(22), & 116-136 .\end{array}$ https://core.ac.uk/download/pdf/328024433.pdf

Anshari, M., Almunawar, M. N., Shahrill, M., Wicaksono, D. K., \& Huda, M. (2017). Smartphones usage in the classrooms: Learning aid or interference? Education and Information Technologies, 22(6), 3063-3079. https://link.springer.com/article/10.1007/s10639-017-9572-7

Aslam, T., Rizvi, S. M. A. S., Ahmad, J. (2020). Virtual Learning Strategies during Covid-19: A Case Study of The University of Lahore, Pakistan. Liberal Arts and Social Sciences International Journal (LASSIJ), 427-441. https://doi.org/10.47264/idea.lassij/4.2.33

Bilgin, S., Kurtkulagi, O., Kahveci, G. B., Duman, T. T., Meryem, B., \& Tel, A. (2020). Millennium pandemic: A review of coronavirus disease (COVID-19). Experimental Biomedical Research, 3(2), 117-126. https://doi.org/10.30714/j-ebr.2020259176

Bloomberg. (2020, March 19). Coronavirus forces $\$ 600$ billion Higher Education Industry. Bloomberg. https://www.bloomberg.com/news/articles/2020-03-19/colleges-aregoing-online-because-of-the-coronavirus

Cetinkaya, L. (2017). The impact of WhatsApp use on success in education process. International Review of Research in Open and Distributed Learning, 18(7). https://doi.org/10.19173/irrodl.v18i7.3279 
Chai, C. S., Koh, J. H. L., \& Tsai, C. C. (2013). A review of Technological Pedagogical Content Knowledge (TPACK). Journal of Educational Technology \& Society, 16(2), 31-51. http://citeseerx.ist.psu.edu/viewdoc/download?doi=10.1.1.299.6205\&rep=rep1\&typ $\mathrm{e}=\mathrm{pdf}$

Chu, R. J., \& Chu, A. Z. (2010). Multi-level analysis of peer support, Internet self-efficacy and e-learning outcomes-The contextual effects of collectivism and group potency. Computers \& Education, 55(1), 145-154. https://doi.org/10.1016/j.compedu.2009.12.011

Creswell, J. W. (2021). A concise introduction to mixed methods research. SAGE.

Fuad, M., Ariyani, F., Suyanto, E., \& Shidiq, A. S. (2020). Exploring Teachers' TPACK: Are Indonesian Language Teachers ready for online learning during the COVID-19 Outbreak? Universal Journal of Educational Research,8(11B), 6091-6102. http://repository.lppm.unila.ac.id/28388/

Gon, S., \& Rawekar, A. (2017). Effectivity of e-learning through WhatsApp as a teaching learning tool. MVP Journal of Medical Sciences, 4(1), 19-25. http://www.informaticsjournals.in/index.php/mvpjms/article/view/8454

Geo News (2020 Febuary 27). Pakistan latest victim of coronavirus. https://www.geo.tv/latest/274482-pakistan-confirms-first

Hew, K. F., Lan, M., Tang, Y., Jia, C., \& Lo, C. K. (2019). Where is the "theory" within the field of educational technology research? British Journal of Educational Technology, 50(3), 956-971. https://doi.org/10.1111/bjet.12770

Jan, A., Rahman, K., \& Khan, I. U. (2020). Socio-Economic and Psychological Impacts of Covid-19: A Case Study of Quarantined Village Ziarat Talash in Dir Lower, Pakistan. Liberal Arts and Social Sciences International Journal (LASSIJ), 4(2), 1-10. https://doi.org/10.47264/idea.lassij/4.2.1

Khanna, D., \& Prasad, A. (2020, October). Problems faced by students and teachers during online education due to COVID-19 and how to resolve them. In $20206^{\text {th }}$ International Conference on Education and Technology (ICET) (pp. 32-35). IEEE.

Khan, K. M. \& Ullah, N. (2021). Post COVID-19 financial distress in Pakistan: Prediction of corporate defaults at Pakistan Stock Exchange. Liberal Arts \& Social Sciences International Journal (LASSIJ), 5(1), 386-400. https://doi.org/10.47264/idea.lassij/5.1.25

Koehler, M., \& Mishra, P. (2009). What is technological pedagogical content knowledge (TPACK)? Contemporary Issues in Technology and Teacher Education, 9(1), 60-70. https://citejournal.org/volume-9/issue-1-09/general/what-is-technologicalpedagogicalcontent-knowledge/

Mishra, P., \& Koehler, M. J. (2006). Technological pedagogical content knowledge: A framework for teacher knowledge. Teachers College Record, 108(6), 1017-1054. http://one2oneheights.pbworks.com/f/MISHRA_PUNYA.pdf

Mohsin, A. K. M., Hongzhen, L., Sume, A. H., \& Hussain, M. H. (2020, June 4). Analysis of the Causes of Moral Injury in the Outbreak of 2019-nCoV. Psychological trauma: Theory, Research, Practice, and Policy. Advance Online Publication. http://dx.doi.org/10.1037/tra0000720

National Institute of Health Islamabad. (2020). COVID-19 live dashboard (Pakistan). https://www.nih.org.pk/novel-coranavirus-2019-ncov/

Ngumbi, E. (2020). Coronavirus closings: Are colleges helping their foreign, homeless and poor

students. USA

Today,

11-14. 
https://www.usatoday.com/story/opinion/2020/03/17/coronavirus-closings-canstrand-poor-foreign-homeless-college-students-column/5054621002/

O'Flaherty, J., \& Phillips, C. (2015). The use of flipped classrooms in higher education: A scoping review. The Internet and Higher Education, 25, 85-95. https://doi.org/10.1016/j.iheduc.2015.02.002

Onyema, E. M., Eucheria, N. C., Obafemi, F. A., Sen, S., Atonye, F. G., Sharma, A., \& Alsayed, A. O. (2020). Impact of Coronavirus pandemic on education. Journal of Education and Practice, 11(13), 108-121. https://genbase.iiep.unesco.org/workspace/applis/epidoc/fichiers/EPIDOC/38698_5 2821_56584_1_PB.pdf

Onyema, E., Nwafor, C., Faith, A., Sen, S., Atonye, F., Sharma, A., \& Alsayed, A. (2020). Impact of Coronavirus pandemic on education. Journal of Education and Practice, 11, 108-121. https://doi.org/10.7176/JEP/11-13-12

Rehman, N., Zhang, W., Mahmood, A., \& Alam, F. (2021). Teaching physics with interactive computer simulation at secondary level. Cadernos de Educação Tecnologia $e$ Sociedade, 14(1),

127-141. http://www.brajets.com/index.php/brajets/article/view/707

Richardson, J. W., Lingat, J. E. M., Hollis, E., \& Pritchard, M. (2020). Shifting teaching and learning in online learning spaces: An investigation of a faculty online teaching and learning initiative. Online Learning, 24(1), 67-91. https://eric.ed.gov/?id=EJ1249283

Saeed, B., Ullah, A. \& Khan, M. A. (2021). Attitude of university students on online teaching under corona virus pandemic situation in Pakistan. Liberal Arts \& Social Sciences International Journal (LASSIJ), $28-40$. https://doi.org/10.47264/idea.lassij/5.1.3

Santos, J. M., \& Castro, R. D. (2021). Technological Pedagogical content knowledge (TPACK) in action: Application of learning in the classroom by pre-service teachers (PST). Social Sciences \& Humanities Open, 3(1), 100110. https://doi.org/10.1016/j.ssaho.2021.100110

Saqlain, M., Munir, M. M., Ahmed, A., Tahir, A. H., \& Kamran, S. (2020). Is Pakistan prepared to tackle the coronavirus epidemic? Drugs \& Therapy Perspectives, 1. https://www.ncbi.nlm.nih.gov/pmc/articles/PMC7095264/

Schmid, M., Brianza, E., \& Petko, D. (2021). Self-reported Technological Pedagogical Content Knowledge (TPACK) of pre-service teachers in relation to digital technology use in lesson plans. Computers in Human Behaviour, 115, 106586. Shulman, L. (1986). Those who understand: Knowledge growth in teaching. Educational Researcher, 15(2), 4-14. https://doi.org/10.3102\%2F0013189X015002004

Shaheen, M., Siraj, U., \& Bhatti, M. N. (2020). Covid-19 Pandemic and its Politico-Economic Implications: A Study of Pakistan. Liberal Arts and Social Sciences International Journal (LASSIJ), 4(2), 42-51. https://doi.org/10.47264/lassij.4.2.4

Shin, T., Koehler, M., Mishra, P., Schmidt, D., Baran, E., \& Thompson, A. (2009, March). Changing technological pedagogical content knowledge (TPACK) through course experiences. In Society for Information Technology \& Teacher Education International Conference (pp. 4152-4159). Association for the Advancement of Computing in Education (AACE).

Shulman, L. (1987). Knowledge and teaching: Foundations of the new reform. Harvard educational Review, 57(1), 1-23. https://doi.org/10.17763/haer.57.1.j463w79r56455411 
The Ministry of National Health Services. (2020). Regulation and coordination. https://covid.gov.pk/stats/pakistan

UNESCO. (2020). COVID-19 educational disruption and response. https://en.unesco.org/news/covid-19-educational-disruption-and-response

Valtonen, T., Leppanen, U., Hyypia, M., Sointu, E., Smits, A., \& Tondeur, J. (2020). Fresh perspectives on TPACK: Pre-service teachers' own appraisal of their challenging and confident TPACK areas. Education and Information Technologies, 25(4), 28232842. https://link.springer.com/article/10.1007/s10639-019-10092-4

Voogt, J., Fisser, P., Pareja Roblin, N., Tondeur, J., \& van Braak, J. (2013). Technological Pedagogical Content Knowledge (TPACK): A review of the literature. Journal of computer assisted learning,29(2), 109-121. https://doi.org/10.1111/j.13652729.2012.00487.x

Waris, A., Atta, U. K., Ali, M., Asmat, A., \& Baset, A. J. N. M. (2020). COVID-19 outbreak: Current scenario of Pakistan. New Microbes and New Infections, 35, 100681. https://doi.org/10.1016/j.nmni.2020.100681

World Health Organization. (2020). Coronavirus disease 2019 (COVID-19): Situation report, 73. https://apps.who.int/iris/handle/10665/331686

Zaidi, Z. I., \& Hussain, M. S. (2019). Technological Pedagogical Content Knowledge (TPCK) and its implication in teacher education. Jamshedpur Research Review, V(XXXVI). 41-46. https://doi.org/10.1080/03055698.2012.713548 